\title{
ATONEMENT IN AFRICAN PLURALISTIC CONTEXT: EXAMPLES FROM THE LUHYA OF WESTERN KENYA
}

\author{
WABOMBA SyCHELLUS NJIBWAKALE*
}

Emmanuel Christian Seminary

\begin{abstract}
The study is a response to the call for papers that focus on African issues and it discusses the issue of atonement. The question which is raised is whether the Jewish and Luhya traditional concepts of atonement are similar or not. To answer this question, I have attempted to explain the understanding of the concept in Jewish tradition before comparing and contrasting this with the Luhya traditional concept of atonement. The study shows that there is a sense of harmony maintained or restored between worshippers and their objects of worship. Through a study of comparative religions, we find various depictions of atonement in different religious traditions. But the goal is the same-the attainment of forgiveness and reconciliation.
\end{abstract}

KEY WORDS: Atonement, Comparative Analysis, Jewish Tradition, Rituals, African Religious Traditions

\section{Introduction}

Etymologically, the term atonement is an Old Testament concept that was developed through the ages until the time of the New Testament when it was perfected. In this sense, atonement cannot be understood without tracing its Old Testament roots. In the Jewish tradition, the concept of atonement dealt with cleansing or purification, or the payment of a ransom. The burnt offering played a vital role in making atonement for sin (Leviticus 1:4; Numbers 15:22-26; 2 Samuel 24:25; Job 1:5; 42:8), and in turning away God's wrath (Genesis 8:20-21; 2 Chronicles 29:7-8). Other offerings that tend to overcome the separation between human beings and God caused by sin are the purification offering (hattat), also referred to as sin offering, ${ }^{1}$ and the reparation offering (asam).

* WABOMBA SYCHELluS NJIBWAKALE (MA 2013, Emmanuel Christian Seminary) is doctoral candidate at Emmanuel Christian Seminary at Milligan, Elizabethton, Tennessee, United States of America. Email: njibwakale@gmail.com.

1 Although associated with atonement for sin, this offering has much to do with purification, e.g. after childbirth (Leviticus 12:6-7). Childbirth was classified under ceremonial uncleanness but was not considered sinful. 
In his 1997 research, Tokunboh Adeyemo cites four theories of sacrifices by Sawyerr under which this concept of atonement will be discussed. These are the gift theory, the propitiation theory, the communion theory, and the thank-offering theory. These theories, if examined keenly, reflect the different ways of sacrifices as will be discussed later. The gift theory views sacrifice as malevolent and man as the liege of deity and/or deities (De Vaux 1961:447). The propitiation theory is for pacifying pleasure due to an offence, thereafter an atoning action directed to God with the sole purpose of saving the life of a person. In the Septuagint (LXX), exilaskesthai means to 'propitiate', while its secondary meaning is to 'expiate' thus, to make complete or satisfactory amends for any wrong, crime or sin (Abe 1996:6). In religious expression, the term connotes the idea of the pagan conceptions of appeasing the god, which according to Abe, 'is inappropriate to Yahwism' (Abe 1996:6). At the same time, it does not carry the religious meaning of propitiating God in the New Testament; instead, it has the general purpose of expiation. The Old Testament sacrifice and the burnt offering are not quite a propitiatory gift but more of a devotional expression to God. In the New Testament, we find no idea of God's wrath being propitiated by the sacrifice of Jesus Christ. It is God in Jesus Christ who reconciles us to himself (2 Corinthians 5:19).

African indigenous religions recognize the use of ritual cleansing, propitiatory, ${ }^{2}$ and substitutionary sacrifices. The aim of these sacrifices is to lessen the anger of divinities and spirits in order to remove the wickedness committed, obtain their favor and restore peace and harmony between the offender and the divinity. The communion theory was popularized by Robertson Smith in his lectures on the 'Religion of the Semites in 1889'. Smith argued that such sacrifices were primitive, especially early Semitic sacrifice, which was a feast in which both the god and his worshippers ate together. Smith viewed the feast as a form of social fellowship. However, communion theory is already outdated since the clan emblem is no longer a regular idea and the emblems eaten do not serve the required purpose of unification with the deities. The purpose of sacrifice is to expose the idea that the life of a victim is made sacred through consecration and not the flesh which the sacrificers ate (Pritchard 1970:450). The expiation theory deals with union with a deity through the immolation of a victim as a representative of man.

These theories correspond with the Bukusu sacrifices in multiple ways. For instance, in ancient times, the propitiatory and purification sacrifice was administered in Bukusu indigenous religion in western Kenya. I will ex- 
plain this with two examples. First, the Bukusu organized a 'rainmaker's festival if there was a long period of dry season. The elders of the community would assemble the community for a ritual cleansing in which an animal (especially a black goat) is killed and blood is sprinkled on the people's heads to ward off all their human miseries which prevent rain from coming on time. Apart from offering sacrifice and sprinkling blood, they would also pray to the gods to grant them long life in line with the Christian concept of eternity in union with God.

Second, the Bukusu believed in the omиfumu (witch-doctor), a divinerpriest who later became the savior of the Bukusu people. This witch doctor would ask that one of the offending members of the community be offered as a sacrifice to redeem the Bukusu people from whatever constant calamities affected them or their property. The act of the omufumu (witch-doctor) was not an organized occasion or annual event, but a once for all life sacrifice for all purposes to save the people.

The main purpose of this article is to explore the subject of atonement within its historical development, its conception in the Old and New Testaments, as well as its modern and postmodern interpretations. I will also examine the subject matter in the light of the African view of atonement, especially of the contemporary practice of atonement in the church in Africa. This is important because the current generation of African Christians only understands the idea of atonement from a western perspective, which uses western language and idioms, introduced by missionaries.

\section{Atonement in the Old Testament}

Scholars of biblical narratives suggest that atonement is an Old Testament concept though they argue that an accurate analysis of Old Testament concepts of atonement is difficult to undertake. Attempts to trace a development of the thought from Israel's early history to the post-exilic era (Cross 1929:59) pose considerable historical and theological difficulties (Castelot 1970:718). Modern scholarship operates mainly on the assumptions of the Wellhausen hypothesis, which regards the Old Testament text, especially the Pentateuch, as the product of a long process of editorial work culminating in the Priestly Writings well after the exile. The scholars assume, for example, that the book of Leviticus, which is rich in sacrifices and thus 'an invaluable source for our understanding of Old Testament concepts of atonement, projects the theology and concerns of post-exilic priestly writers 
back into the time of Moses' (Ekem 2005:21). Roland De Vaux (1961:424) offers an insightful discussion of this subject, as he notes that many scholars are confronted with several hypothesis regarding the origins and development of ancient Israelite rituals of atonement. Before I go further, it is appropriate to establish the definition of atonement that will inform the argument of this article.

The Hebrew word kipper means to make atonement. The biblical meaning of the word may be rendered as 'covering up' (Exodus 25:17; Leviticus 16:2); it can also mean to 'ransom' (Exodus 30:17; Numbers 35:31-32) or 'purging' (Isaiah 27:9; Jeremiah 18:23). Typically, atonement involves the process of covering up sins or expiatory deeds meant to divert divine wrath and to bring about reconciliation. The Old Testament concept of atonement derives mainly from Israel's sacrificial system. It is sufficient to say that atonement was governed by the covenant relationship between YHWH and his chosen people, Israel. In a covenant relationship, both parties have a part to play. YHWH is to protect and bless Israel and the latter is to obey. In the text of the Old Testament, atonement is necessitated by Israel's failure to fulfill her part of the covenant. As a result, there is a strain in relationship which requires atonement for restoration to the original state.

Atonement involves God giving himself to his people and the people uniting with God, restoring the once broken relationship between human beings and God. As spelled out in Leviticus 16, the High priest goes to sacrifice at the tabernacle for himself, his family, and for the entire community of Israel. The idea here is for the High Priest to purify himself and his family before his sacrifice on behalf of the people. God looks for the purity of the High Priest on behalf of the whole community that he represents. It calls for the fulfillment of divine judgment on the sins of humanity and the removal of that barrier of sin between God and humanity. The people initiate this turning back to God and God responds by perfecting the purification process. As a result, the relationship between humanity and God is finally restored. Generally, atonement is a religious concept in which obstacles to reconciliation with God are removed, usually through sacrifice. Most religions have rituals of purification and expiation by which the relation of the individual to the divine is strengthened.

The Day of Atonement was celebrated annually on the tenth day of Tish$r i$ (September-October) and is known today as Yom Kippur (Leviticus 23:2732). Yom Kippur was the most solemn and strictest holiday in Israel's history. No form of work was permitted on that day. Sacrifices and animal blood were used to 'wash' the priest and the entire people. In other words, atonement was God's way of dealing with the problems posed by sin and reconciling sinners into right relationship with God (John 1:29; Romans 8:11; 2 Corinthians 5:18-19; Galatians 1:4; Hebrews 2:9, 18). On the Day of 
Atonement, the high priest entered the Holy of Holies to cleanse himself through sacrifices before meeting God. So, The Day of Atonement was a very significant day in which things were put right for the whole community in a highly symbolic manner.

The Old Testament deals with human predicaments as reflected in various texts of the Old Testament (especially the Pentateuch). Some of these predicaments are relational in nature as in Genesis 2-3 where the relationship between the man, the woman and God is questioned and ruined. Others are social, as in the stories of Genesis 4-11 which explain inter-human disorder at every stage such as envy, violence, murder, corruption, vengeance, and arrogance. There is also a covenantal aspect to human predicament as shown in Exodus 32-34, which deals with God's relation with Israel. Lastly, there is the legal aspect exemplified by Deuteronomy 32 as well as the ritual aspect such as Ezekiel 4:12; 36:16-17.

The Passover is one way by which YHWH puts things right with humanity. Leon Morris, in his discussion of the theology of the Old Testament, spells out three key elements of the Passover ritual and theology, namely, protection from wrath and destruction, liberation from oppression, and consecration in Yahweh (Chalk and Wright 2008:73). Therefore, the Passover speaks not only of Yahweh's redemptive commitment to Israel, as outlined in history, but also of Israel's ethical commitment to Yahweh (Exodus 19:6). The same picture is reflected in the combination of Passover and holiness in the writings of Apostle Peter (1 Peter 1-2). The apostle Paul likewise interprets the Passover tradition ethically (1 Corinthians 5:6-8). Wright notes that the role of the atoning blood in the four sacrifices was clearly to cleanse everything that was associated with God in the sanctuary, and at the same time to cleanse the people from the uncleanness of accumulated sin (Wright 2008:78).

Besides the background of atonement found in the Old Testament, the Intertestamental literature provides some clues on the subject of atonement. Sacrifices of one kind or another were a normal way of making atonement. In the Book of Jubilees ${ }^{4}$ 50:11, morning and evening sacrifices were to be maintained even on the Sabbath. In Maccabees ${ }^{5}$ 12:40-45, Judas Maccabee made atonement for the fallen heroes of the Jewish resistance army who sinned by wearing amulets belonging to the idols of Jamnia. This reflects the changing understanding of atonement, as Jews moved away physically from Jerusalem and the temple. The Old Testament and Intertestamental 
writings offer a better understanding of the concept of atonement in the New Testament.

There is also evidence of making atonement through prayers and fasting. According to the book of Psalms of Solomon 3:9, the supplicant makes atonement for sins of ignorance by fasting and afflicting his soul. Almsgiving also has an atoning significance according to Ben Sirach ${ }^{6}$ 29:12. In Testament of Levi, we find angels playing a role in atonement. In Testament of Levi 3:5, archangels ministered and made propitiation to the Lord for all the sins of ignorance. In Levi 5:6, the angel escorted Levi in his visionary experience. All these instances of angelology are woven into the Jewish concept of atonement.

\section{Atonement in the New Testament}

The concept of atonement is central to many religious traditions. ${ }^{7}$ In the New Testament, the subject has sparked heated discussions from the early apostolic period and era of the Church Fathers, to the modern period. However, the New Testament views, which also influenced the thinking of subsequent generations of Christian theologians, were derived, to a considerable extent, from views that were held in the Old Testament and Intertestamental periods (Ekem 2005:1).

Although atonement generally means reconciliation, that is, the overcoming of estrangement and breaking down the dividing wall of partition (Ephesians 2:14) the New Testament understands atonement as the state of being 'at one' or reconciled after two parties have been estranged from each other (Thornton 1937:11). In relation to Christian doctrine, it has been used to refer to reconciliation with God through the death of Jesus Christ for the sin of humankind. In particular, it touches on the vital question of God's intervention in history to deal with the problem of sin, especially through Christ's sacrificial death on the cross (Cross 1958:101). According to Allan Mann, a biblical understanding of atonement is concerned above all with the restoration of a mutual understanding and an unpolluted divine/human relationship, not with the appeasing of a God angered by the misdeeds of his creatures (Mann 2005:94). ${ }^{8}$ In his reaction to Alan Mann's Greek by his grandson of the same name. gions have ways of ensuring that harmony is either maintained or restored between the worshippers and their object of worship. 
statement above, Howard Marshall confirms that Mann's statement represents the view of many theologians who reject the concept of penal substitution as the principal means, or even as a subordinate means of understanding the significance of Christ's death (Marshall 2008:49). The rejection stems from the fact that such an understanding goes with the belief that God could never save sinners without having first exercised violence on his only son. Thus, the violence shows that penal substitution cannot be the right way to understand the importance of the cross.

Despite the frequent rendering of the Hebrew verb kipper, as 'to cover', in the King James Version of the Old Testament, the word atonement occurs only once in the New Testament of the same version, that is, in Romans 5:11 where it is translated from the Greek noun katallage, which means reconciliation. However, the question is do the two words carry the same in meaning? The opinions of scholars differ on this point and some have questioned the validity of the meaning according to the same significance to both. Vine (1940:86) and Richardson (1958:215), among others, argue for a clear distinction between the two words, and show that whereas reconciliation signifies an accomplished restoration of fellowship with God, atonement denotes the means by which reconciliation is effected namely the sacrificial death of Christ on the cross. Vine contends that atonement must be understood as 'at-one-ment' (Vine 1940:86). In his definition of reconciliation, Mozley (1974:11) argues that 'as regards the two words, "atonement" and "reconciliation", it may be said that whereas the idea of reconciliation is implied in the word "atonement", however, the latter may be interpreted the reverse, if atonement is not interpreted as at-one-ment, is not necessarily the case'. Therefore, if reconciliation is the state or condition of being 'atone' with God, atonement refers to the means or act by which this reconciliation is made possible. Richardson also contends that 'this usage is entirely in harmony with the use of atonement in the Old Testament as meaning that by which expiation is made' (Richardson 1958:215).

In my own understanding of the subject, Hodges (1955:10) has rightly claimed that, theologically, the term 'atonement' applies to the reconciliation of God and humankind. We could employ it either as a name for the fact of reconciliation, or more narrowly, as a name for a particular act on the part of the reconciler which makes the reconciliation possible. In the first of these senses, atonement is co-extensive with the whole work of God in Christ. In Hodges' (1955:10) view, 'the whole of that work can be seen as a bridging of gulfs, a removal of estrangements, and a restoration of unity'. Although such an explanation may not capture the whole meaning of atonement, I wish to contend that atonement is essentially an all-inclusive soteriological concept which involves the entire scope of God's redemptive 
work in Christ from the incarnation to Christ's present heavenly ministry and even beyond.

I will now consider some key concepts of atonement in selected writings from both the Old Testament and the New Testament in order to offer some biblical interpretation from a Luhya perspective. The Old Testament tells the story of atonement in diverse ways. Although the Pentateuch covers the widest grounds on the subject, other writings of the Old Testament also make their own distinctive contributions. The question to reflect on is how do the issues raised above relate to biblical hermeneutics in an African pluralistic setting? Later, I will attempt to illustrate this with a case study of Leviticus 16:17.

\section{Biblical Interpretation from a Kenyan Perspective. The Case of Leviticus 16:17}

The book of Leviticus, especially chapter 16 which describes the Yom Kippurim (the Day of Atonement), offers a very comprehensive and interesting view of atonement. It has a highly theological material on the subject of atonement. Regarding biblical interpretation in the Kenyan pluralistic context, this section would employ a dialogical approach to the concept of kapporet in Leviticus 16:17 (that is, hilasterion in Romans 3:25a). In other words, an attempt will be made to create a dialogue between the biblical text with its embedded world-views, and the Kenyan context as well as the western interpretations of it-via translations that reflect the world-views of translators and their target audiences. Such a dialogue is indeed validated by the fact that these English interpretations/translations are also used by some members of the Kenyan public for devotional and academic purposes. First, I shall attempt to outline and comment on some translations of Leviticus 16:17 in selected western and Kenyan languages. Since Kenya has 42 different dialects, I will focus on the Luhya dialect with which I am familiar and Kiswahili which is the common national language:

There shall be no man in the tabernacle of meeting when he goes in to make atonement in the Holy Place until he comes out, that he may make atonement for himself, for his household and for all the assembly of Israel ( $\left.\mathrm{NKJV}^{9} 1982\right)$. 


\section{New International Version}

No one is to be in the tent of meeting from the time Aaron goes in to make atonement in the Most High Place until he comes out, having made atonement for himself, his household and the whole community of Israel (NIV 1984).

No one shall be in the tent of meeting from the time he enters to make atonement in the sanctuary until he comes out and has made atonement for himself and for his house and for all the assembly of Israel (NRSV 1989).

No other man shall be within the Tent of the Presence from the time when he enters the sanctuary to make expiation until he comes out, and he shall make expiation for himself, his household, and the whole assembly of Israel (NEB 1976).

No one else is allowed inside the Tabernacle when Aaron enters it for the purification ceremony in the Most Holy Place. No one may enter until he come out again after purifying himself, his family, and all the congregation of Israel, making them right with the Lord (NLT 1996).

The translation in both Luhya and Swahili are as follow:

\section{Swahili Translation}

Wala hapatakuwa na mtu katika hema ya kukutania, wakati aingiapo ili kufanya upatanisho katika patakatifu, hata atakapotoka nje, baada ya kufanya upatanisho kwa ajili ya nafsi yake mwenyewe, na kwa ajili ya nyumba yake, na kwa ajili ya mkutano wote wa Israeli (Mambo Ya Walawi 16:17, United Bible Society, Kenya, 1979).

Mtu yeyote haruhusiwi kuwa ndani ya Hema la Kukutanisha kuanzia wakati Aroni anapoingia kufanya upatanisho ${ }^{10}$ katika Patakatifu pa Patakatifu mpaka atakapo toka nje, baada yakujifanyia upatanisho yeye mwenyewe nyumba yake pamoja na jumuiya yote ya Israeli (Mambo Ya Walawi 16:17, United Republic of Tanzania, 2006).

\section{Luhya Translation}

Omundu yesi yesi sa fukililwa khuba mukari mwe liema lie liambaasia ${ }^{11}$ Aruni naba nengengila khukhola liambasia abundu arabora we burabora paka nalarura no direct word for atonement in Kiswahili.

11 Liaambasia is the Luhya word for atonement. It is closer in meaning but it is not the direct translation of atonement in the Bukusu dialect. 
enje, namalile khukhwiambasia niye omwene nende enju yewe nende luya lwoosi lwa Israeli (Kitabu cha Balevi 16:17, my own translation).

Of these translations, the NKJV, NIV, and NRSV render kapporet as 'to make atonement' without indicating whether it should be understood as a sacrifice of propitiation or expiation. The NEB uses the phrase 'to make expiation' instead of 'make atonement' whereas the NKJV and NEB begin by using the phrases 'no man' and 'no other man'. Whether this use of man is generic or gender specific is debatable. The NIV and NRSV use the phrase 'no one', which suggests that no individual regardless of gender or age was to be present in the Tent of Meeting. However, all versions agree that the High Priest made atonement for himself, his household and the entire community of Israel. The NIV and NKJV identify the place for atonement as the 'Most High' or 'Holy Place' while the NRSV and NEB refer to the place as 'the sanctuary' where atonement is made. The NLT explains what Aaron did in the tabernacle, which is, performing the purification ceremony for himself, his family and all Israel. Like the NEB, it avoids the use of the word atonement.

In the Luhya and Swahili translations, the meaning of the word 'atonement' is not clear therefore it has been replaced with a word closer in meaning to it. The word substituted for atonement in the first two Swahili versions is upatanisho whereas in the Luhya version, it is liambaasia. These versions look more like paraphrases than real translations, especially in terms of the word atonement. This, indeed, is a crucial hermeneutical point which affirms the viewpoint that reconciliation rather than atonement is at the centre of the Kenyan/African understanding of the concept. These versions understand and emphasize reconciliation in their translations which means there is no direct word for translating atonement. Thus, what is important is for the readers to understand the main thrust of the passage in their own context. What is interesting about the above versions is their rendering of atonement as upatanisho/liambaana-reconciliation.

In the New Testament, we find the early apostolic witness that records God's saving act through the atoning work of Jesus Christ. The understanding of these records, as we have them, derives from early Christian preaching, teaching, and worship based partly on the sayings of Jesus and partly on the writers' own interpretation of their implications for their audiences (Ekem 2005:37). The perception of the death of Christ as atonement is common to all New Testament writers who believed that Christ died for a sinful world in accordance with the divine purpose. However, since Paul's writings are believed to be among the earliest writings in the New Testament, it would be appropriate to consider them before other writings. In this paper, I will focus on one text from the letters of Paul and provide the biblical interpretation from the Luhya viewpoint.

PERICHORESIS 14.1 (2016) 
Paul's writings raise several issues regarding atonement. ${ }^{12}$ However, Paul did not write in a vacuum. To a considerable extent, he was indebted to both the tradition of Judaism in which he grew up and the Early Church tradition upon which he based his subsequent expositions. In 1 Corinthians 15:3 and Romans 1:3-4, we see allusions to the early Christian traditions on the death of Christ. However, Paul's view of atonement was a reinterpretation of these early traditions on the basis of his personal understanding of Christ's redeeming work. Generally, Paul covered most of the discussion of atonement though other New Testament writers also make some notable contributions. Since this work focuses on biblical hermeneutics in an African pluralistic setting, the following paragraphs will focus on a short case study of Romans 3:25a.

\section{Biblical Interpretation in a Luhya Setting. The Case of Romans 3:25a}

In Romans 3:25a, Paul presented Jesus as the one whom God 'put forward' as hilasterion dia [tes] pisteos en to autou haimati. Scholars have argued about the real meaning of hilasterion in relation to the whole text. However, Paul employed a creative use of his knowledge of the Jewish Scriptures to reinterpret this idea of atonement from a Christological perspective. On the interpretation of this text in a Luhya Kenyan pluralistic setting, the text sets off a dialogue about the idea of hilasterion in Romans 3:25a. As I have done before, I shall again compare the Kenyan and western interpretations through the translations.

\section{English Translations}

...whom God put forward as an expiation by his blood to be received by faith $\left(\mathrm{RSV}^{13}\right.$ 1952).

...whom God put forward as a sacrifice of atonement [footnote: a place of atonement] by his blood, effective through faith (NRSV 1989).

God presented him as a sacrifice of atonement through faith in his blood (NIV 1984). some letters or verses, this does not in any way dismiss the contribution of the Apostle on the subject of atonement.

13 The RSV and NEB represent respectively the Revised Standard Version and the Revised English Bible. 
For God sent Jesus to take the punishment for our sins and to satisfy God's anger against us (NLT 1996).

For God designed him to be the means of expiating sin by his death, effective through faith (REB 1989).

Below, the Kenyan translations of Romans 3:25a will be rendered in two languages—Luhya and Swahili:

\section{Luhya Translation}

Weele wahana Yesu nio, khulwe lifwa liewe ole khuba engila niyo bubwooni bwe babandu bubelwakho khubirira mulisubula lwabe mu niye (Lilaka Liya lie Lubukusu).

\section{Kiswahili Translations}

Yeye ambaye Mungu alimtoa awe dhabihu ya upatanisho kwa njia ya Imani katika damu Yake (Biblia Mpya Ya Tanzania, URTZ, 1997).

Mungu alimtoa awe dhabihu ya upatanisho kwa njia ya Imani katika damu yake (Bibilia Takatifu, SNT, 1989).

From the above, we would note that the NIV and NRSV render hilasterion as 'a sacrifice of atonement' thereby exposing its common sense without interpreting whether it should be understood as a sacrifice of propitiation or expiation. It is interesting to note also that the NRSV footnote has the rendering 'a place of atonement'; this suggests that the translators were also keen to acknowledge the kapporet imagery in Paul's thinking. The RSV and REB see Jesus' atoning work as 'a means of expiation.' When it comes to the idea of how this is actually achieved and appropriated, the above versions present us with some interesting feedback. The RSV, REB, and NLT show that Jesus is put forward/designed/sent by God as hilasterion by means of his blood and this accomplishment is appropriated by faith. The REB does not use the term 'blood' but instead opts for the meaning, 'by his death'. However, the NIV conveys the fact that Jesus' atoning work is appropriated through faith in his blood. Taking into consideration the centrality of the concept of justification in Pauline thought, it is unlikely that Romans 3:25 would place emphasis on faith in the blood of Jesus rather than faith in Jesus himself whose blood or life given up in death becomes God's required means of atonement.

These versions demonstrate the challenges involved in translating important texts that can really shape the theologies of Christian communities. Special care must be taken in dealing with the exegesis and interpretation

PERICHORESIS 14.1 (2016) 
of such texts; otherwise the meanings would be lost. From the above translations in both Swahili and Luhya languages of Kenya, the 1989 SNT and the 1997 URTZ versions follow exactly the NIV of 1984 and NRSV of 1989 when describing the atoning process in Romans 3:25. As in the 'Lilaka liya lie lubukusu' version, both give special attention to the 'faith component' but fail to incorporate effectively the 'blood component'. This is rather disappointing because the translators should have captured the theological and linguistic nuances of the text, but rather they worked on the revision which somehow distorted the meaning of the text. At the same time, some key words or phrases are lost since there is no direct word or phrase that corresponds to them in the other language. For instance, we would notice that in the Luyha and Kiswahili translations, no direct word for atonement is used. Instead, the words upatanisho (Swahili) and liambaasia (Luhya) are used as substitutes for atonement.

In the above versions, is there a viable alternative to the rendering of $h \mathrm{i}$ lasterion in both the Old Testament and New Testament? I will attempt to answer this question by examining briefly sacrificial concepts among the Bukusu people of western Kenya, a sub-tribe of the Luhya people. The Luhya people form the second largest ethnic group in Kenya. Since they share common views, what will be said of the Bukusu people applies, to a considerable extent, to these other Luhya people.

The term sacrifice is defined simply as renunciation for a motive or giving up of something important for the sake of another that is of much worth in value. In this definition, there is no specific element of religion but no religion exists without any form of sacrifice. In religious terms, a sacrifice could be defined as an act of relinquishing or offering a consecrated object or victim for the moral and spiritual benefit of the individual or group concerned (Sofola 1983:143). Sofola define sacrifice as 'a religious act which, through the consecration of a victim, modifies the condition of the moral person who accomplishes it or that of a certain object with which he is concerned' (Sofola 1983:143). According to Augustine, every work done which enables a human being to have union with God is sacrifice in its general usage (Sofola 1983:143). These definitions are not different from the understanding of sacrifice by the Bukusu people of western Kenya as shown seen below.

The Bukusu sacrifices are offered to a spirit, however indefinite, who is supposed to be more powerful than human beings in their normal state. In some cases sacrifices are offered to ancestors who, now spirits, are more powerful than the living and in rare instances are more powerful than the Supreme God. The Bukusu people, like other Africans, believe that God is the creator of everything including the society. The sacrifices which are diverse in nature are also offered for diverse purposes. In other words, there 
is no single reason for the sacrifice. Mbiti (1970:179) notes that the sacrifices are acts of restoring the ontological balance between God and humans, between spirits and humans, and between the departed and the living. In other words, Mbiti upholds the communion theory. He further explains that sacrifices are also acts and occasions of making and renewing contact between God and humans. When they are directed, they are a symbol of fellowship, and recognition that the departed are still members of their human families, and tokens of respect and remembrance of the departed (Mbiti 1970:179). Mbiti, with his privilege of Christian education and missionary influence, tries to justify and elevate African indigenous religions.

The Bukusu expression for sacrifice is the term khuosia. As a matter of fact, khuosia stands on the principle of reciprocity, connoting an expression of gratitude for what the benevolent spirit world has done for the community. This is expressed in the Bukusu sacrificial thought as khuosia khwe liliekhoyela which means 'sacrifice of thanksgiving'. On the other hand, there is also a sense in which khuosia can be done voluntarily and in a nonutilitarian fashion, for instance, through an act of giving which expects no return. One thing to note is that although khuosia is tentatively sufficient as a term for sacrifice, it is not exhaustive in itself. In fact, the term carries several semantic components that reflect the complexity of the Bukusu sacrificial system. Central to this system are the ideas of liliekhoyela, liambaana, sianwa, and libelanila, terms which may be grouped together, as Sawyerr has done, under the general concepts of propitiation, expiation, reconciliation and gift. In an actual sense, these virtues are designed as a means of dealing with evil in the community in order to ensure peace, harmony and prosperity for families and individuals.

Liliekhoyela is seen as a sign of happiness after reconciliation, sealing the bond between the deities and the community. These rituals, in a way, appear similar to the atonement rituals in Leviticus. In Leviticus, we have atonement rituals for cleansing or purification (Leviticus 12-15). Childbirth (12:6-8), leprosy (14:10-32), and bodily discharge (15:13-15, 25-30) all require atonement by blood sacrifice (Belousek 2012:177). However, liambana connotes the idea of a bond of agreement between the deities and the community when both parties participate in the sacrificial meal in order to ratify the fact that evil has been dealt with.

Sianwa serves as a gift that has been realized in the family or community after reconciliation following a state of alienation. For instance, when a woman delivers a baby after several years of barrenness, a sacrifice is made to appease the evil spirit(s) that hindered the coming of the child. Such a child is sianwa (gift) and is given a special name like Makokha meaning the 
'one long awaited for', that is, regardless of the child's gender. The deities are pacified with the blood ${ }^{14}$ of a sacrificial victim and peace is established between the offended deities and the offending community or individual. The victim lays hand on the sacrificed animal transferring the sins and life principles to the animal. The animal becomes a substitute in the sacrifice and killing the animal means symbolically death or the carrying away of sins. Blood in the sacrifice is an important element to the Bukusu people just as it is in the African tradition at large. As the blood spills out and rolls down, the people see life and prosperity in the victim, not death. The blood brings the new life of the sacrifice into contact with the deity. In other words, the relationship between the sacrificer and the deity is re-established if strained or strengthened if it was weak.

Libelanila is offered when a person is being integrated into normal life of the community after a period of confinement such as family differences, recovery from serious illness that the community thought incurable, or when a man had run away from a customary initiation like circumcision. A white hen may be used in performing a sacrifice. The sacrifice is not necessarily directed to deities or ancestors, but is meant solely to initiate one into a new phase of life in the community. However, since the deities and ancestors permeate all spheres of community life, they cannot be regarded as silent or passive characters in the libelanila process.

The significant thing with sacrifice as I have observed in the Bukusu tradition is that it is regarded as an element of external worship. It is done in a way that not only the worshipper, but also the deity feels something internally in response to the prayer. A sacrifice achieves its religious significance when the external action expresses the real inward feelings of a person so that it can be received favorably by the deity. De Vaux notes that if a sacrifice fails in this aspect, it is no longer a religious act (De Vaux 1961:451). The external sacrifice expresses the inward manifestation of the inward sacrifice. As Ubruhe (1996:15) puts it, internal sacrifice is the soul of external sacrifice.

In ancient Judaism, external sacrifice stands independent of the internal sacrifice, but in African indigenous religion, the two are inseparable. Among the Bukusu people of western Kenya, as in any other African context, a sacrifice is performed after serious consultation with the deity and the sinner. The sinner has to acknowledge that he or she has transgressed against the divine and confess the sin. Ideally, sacrifice as an element in the act of worship is significant in all religions. 
The importance of sacrifice in African indigenous religions has prompted De Vaux (1961:451) to view sacrifice as the 'open sesame' to the African heart in the communication of the Christian message. De Vaux admonishes African theologians (including this writer) who conduct research on African sacrifices to distinguish between those of placation and those entailing removal of stains. Sawyerr (1969:80) claims that this will enable the presentation of the Gospel in a way that can evoke a healthy meaning of Christ's death and resurrection. With this understanding, the contemporary generation can see the concept of atonement from their context rather than with western lens. It is important that the contemporary generation of African ministers preach the Christian message of atonement from the traditional context in which they grow up.

Context is important. For example the Bukusu people of Kenya have popular legends about certain individuals who suffered vicariously for their communities in order to avert calamities. These individuals are believed to have been offered, on their own volition, as human sacrificial victims in response to crisis situations that could not be dealt with through conventional animal sacrifice. Such a legendary figure among the Bukusu is called omulame or silaamo that is in reference to the act. Some of the instances that prompt silaamo are a deadly epidemic and failure to have children. According to the legend, the victim is made to drink the blood from a sacrificial animal and spit out the first sip on the entire community for their healing and purification before swallowing the rest of the blood. As a result, the calamity is averted and harmony is restored to the community.

In the Bukusu sacrificial system, one can view such an event as an illustration of liambana, sianwa, liliekhoyela, and libelanila (reconciliation, gift, thanksgiving, and forgiveness). However, the legend neither alludes to a divine initiative nor depicts omulame as an innocent sufferer. There is a sense in which it can serve as a culturally relevant starting point for interpreting the experience of the Omunyakhani omurumikhi-Yehovah (Suffering Servant-YHWH) in Isaiah 53. Based on the Bukusu sacrificial system as illustrated in this legend Omulame, how can the idea of liambana adequately fit with the idea of hilasterion in Romans 3:25a and of kapporet of Leviticus 16:17? God took the initiative by 'putting Jesus ahead' as a means of hilasterion through his blood that is appropriated $b$ faith for justification to be operative in a person's life. It was also God who directed the High Priest to sacrifice an animal at the altar as a means of kapporet so that the blood of the sacrificed animal could be operative in the life of the High Priest, his household, and the whole assembly of Israel. Therefore, it appears that $l i$ ambana (hilasterion) and libelanila (kapporet) are more appropriate interpretation of the process described in Romans 3:25a and Leviticus 16:7.

PERICHORESIS 14.1 (2016) 


\section{Conclusion}

I have considered the concept of atonement from various angles to show that sacrifices differ in their purpose, aim, and recipient. I have also noted that in the African thought, the more urgent the need to restore and maintain a cordial relationship with the deity/deities, the higher the condition a person is ready to fulfill. Thus, the practice of human and animal sacrifice in African indigenous religions is regarded as a necessity. My argument has shown that the sacrifices done by the Bukusu people of western Kenya do not help to elucidate Jesus' death for humans in order to reconcile them to God. In other words, the contextualization of the Christian message in Africa cannot be based on such sacrifices. It is worth noting that the animals used in sacrifice were innocent and in the case of humans, the victims did not give their lives voluntarily. In this respect, their death cannot be termed vicarious.

Atonement enables human beings to be reconciled to God, to be justified, forgiven and made righteous in God's sight. God does not overlook sin. The penalty for sin must be paid, and this was accomplished on the cross. Not only was the debt of sin paid, but it also made possible the equally miraculous act of imputing the perfect righteousness of Christ to all who believe. The central goal of the Old Testament atonement was to heal the broken relationship between God and his chosen people, Israel. The same thing applies to the work of Jesus Christ which required that he took our place. He bore the punishment of our sins, bringing us pardon and reconciliation with God by his righteousness just as the sacrificed animal and its blood washed away the sins of the children of Israel restoring them back as children of the covenant to God.

Paul captured the essence of the atoning work of Christ in his statement, 'God made him who had no sin to be sin for us, so that in him we might become the righteousness of God' (2 Corinthians 5:21). Paul was very much aware of and familiar with the Jewish cult, and he explained that God has now revealed himself to us in a unique way through the representative/substitutionary sacrifice that Jesus offered by means of his blood. The sacrifice cleanses our sins even as we exercise our faith in Jesus (Romans $3: 21-26 ; 5 ; 8)$. In this sense, Jesus has become the new kapporet or hilasterion-representative of a revelatory way of atonement.

As God in the flesh, Jesus atoned for our sins on the cross. He who was fully human and fully divine became the substitute for all sins and for all sinners. We look to the cross and the atoning work of Jesus Christ for our salvation. The people of the ancient Near East looked at the altar of sacrifice for their cleansing and reconciliation but we believe that Christ's atonement is sufficient to save not only us but the whole world, because he was not a mere man but God in the flesh: 'For God so loved the world that he gave 
his one and only Son, that whoever believes in him shall not perish but have eternal life' (John 3:16). This is the message that ministers should preach to the church today. The message should be made clear that Jesus atoned himself on our behalf and that animal sacrifice is no longer relevant in our Christian generation.

The case study of Romans 3:25a and Leviticus 16:17 with special reference to the idea of hilasterion and kapporet underscores the idea of biblical interpretation in a multi-cultural setting. Therefore, it is important that the translation of the Bible into local African languages and its analysis in relation to the original texts serve as important tools in proclamation and teaching of the gospel for those serving in African contexts. This has far-reaching implications for the development of Study Bibles in local languages. In the words of Wambudta (1980:31), we are being called upon to develop 'a properly biblically grounded reformation of African thought' emerging from the encounter between Judeo-Christian and African world-views. Thus, translating the Bible into local languages plays a vital role in understanding the meaning of particular terms such as atonement.

When the missionaries came to Kenya, especially to western Kenya among the Luhya people, they came with a high degree of confidence in the power of Christianity and American economic and social order propelled by the Great Commission enabled them to go into all the nations baptizing and making disciples of all people. They were insensitive to local beliefs and culture including sacrifice which would have been a hindrance to the Christian message. Today, Christianity has spread to all nooks and corners of Africa, although the emergent church remains weak. I agree with Kalu (1979:21) that for Christianity in Africa to be strong and deeply rooted, it must be traditionalized in African culture so that the dead wood in both can be destroyed and a new form can emerge. The use of indigenous examples can help the younger generation to understand the Christian message from their own context. In that way, traditional practices especially sacrifice could become a means to the heart of the Gospel message.

The salvation of human beings is the fundamental basis for all the redemptive acts of God in the Bible, in both the Old Testament and the New Testament. Different theological concepts have elucidated the divine process by which this act of God was instituted in the past and consummated in the person and work of Jesus Christ. God was experienced through practical and vivid life experiences of the Jews. Today, God is experienced through faith in our Lord and Savior Jesus Christ. 


\section{Bibliography}

Abe G (1996) Redemption, Reconciliation, Propitiation: Salvation Terms in an African Milieu. Journal of Theology for Southern Africa 95(3):3-12.

Adeyemo T (1968) Salvation in African Tradition. Nairobi: Evangel Publishing.

Belousek DWS (2012). Atonement, Justice, and Peace. Grand Rapids, MI: Westminster/Eerdmans.

Castelot JJ (1970) Religious Institutions of Israel [Jerome Biblical Commentary]. London: Geoffrey Chapman.

Chalk S, Wright C (2008) The Atonement Debate. Grand Rapids, MI: Zondervan.

Cross FL (1958) The Oxford Dictionary of the Christian Church. London: Oxford University Press.

De Vaux R (1961) Ancient Israel: Its Life and Institution. London: Longman.

Ekem JDK (2005) New Testament Concepts of Atonement in an African Pluralistic Setting. Accra: SonLife Press.

Hodges AH (1995) The Pattern of Atonement. London: SCM Press.

Kalu OU (1979) Church Presence in Africa: A Historical Analysis of the Evangelization Process. In Appiah-Kubi K, Torres S (eds) African Theology en Route. Maryknoll, NY: Orbis.

Mann A (2005) Atonement for a Sinless Society: Engaging with an Emerging Culture. Paternoster: Milton Keynes.

Marshall HI (2008) The Atonement Debate: The Theology of Atonement. Grand Rapids, MI: Zondervan.

Mbiti JS (1970) Concepts of God in Africa. New York, NY: Praeger Publishers.

Mozley JK (1974) The Doctrine of Atonement. London: Duckworth.

Pritchard EEE (1970) Nuer Religion. Oxford: Clarendon Press.

Richardson A (1958) An Introduction to the Theology of the New Testament. London: SCM Press.

Sawyerr H (1969) Sacrifice. In Dickson KA (ed) Biblical Revelation and African Beliefs. London: Ellingworth Press, pp. 57-82.

Sofola Z (1983) Edi: The Carrier as a Saviour among the Ife. In Adegbola A (ed) Traditional Religion in West Africa. Ibadan: Daystar, pp. 141-146.

Thornton LS (1937) The Doctrine of the Atonement. London: Unicorn Press.

Vine WE (1940) Expository Dictionary of the New Testament Words. New Jersey, NJ: Fleming Revell Company.

Wambudta DN (1980) Hermeneutics and the Search for Theologia Africana. $\operatorname{AThJ} 9(1):$ 31-32. 